\title{
Paleoseismology of the Chelungpu Fault during the past 1900 years
}

\author{
Wen-Shan Chen ${ }^{\mathrm{a}, *}$, Kun-Jie Lee ${ }^{\mathrm{a}}$, Long-Sheng Lee ${ }^{\mathrm{a}}$, Daniel J. Ponti ${ }^{\mathrm{b}}$, Carol Prentice ${ }^{\mathrm{b}}$, \\ Yue-Gau Chen ${ }^{\mathrm{a}}$, Hui-Cheng Chang ${ }^{\mathrm{c}}$, Yuan-Hsi Lee ${ }^{\mathrm{c}}$ \\ a Department of Geosciences, National Taiwan University, 245 Choushan Road, Taipei 106, Taiwan, ROC \\ ${ }^{\mathrm{b}}$ US Geological Survey, Menlo Park, CA, USA \\ ${ }^{\mathrm{c} C e n t r a l ~ G e o l o g i c a l ~ S u r v e y, ~ M i n i s t r y ~ o f ~ E c o n o m i c ~ A f f a i r s, ~ T a i p e i, ~ T a i w a n, ~ R O C ~}$
}

\begin{abstract}
The 1999 earthquake brought about 80-km-long surface ruptures along the Shihkang, Chelungpu, and Tajienshan Faults, central Taiwan. Several trenches have been excavated across the Chelungpu Fault of the middle segment. The surface ruptures display clear scarps ranging from 0.2 to $4 \mathrm{~m}$ high, showing a complex geomorphic pattern due to coseismic faulting and folding. In the study, measurement of the vertical offset or structural relief was taken with reference to the hanging wall beyond the trishear deformation zone. Therefore we suggest that, for the measurement of offset, we should disregard the trishear zone, and that structural relief on the hanging wall should be represented as a real vertical offset. The net slip is then calculated from the structural relief and dip angle of the thrust on a vertical plane along the slip direction. Through the excavation of a pineapple field across the Chelungpu Fault, we are able to provide evidence of at least four earthquake events for the past about 1900 years, including the 1999 earthquake. Furthermore, based on the radiocarbon dates and historical record, the timing of the penultimate event is bracketed to be between 430 and 150 years ago, and the average recurrence interval is less than 700 years. These data indicate that the average slip rate is about $8.7 \mathrm{~mm} / \mathrm{yr}$ for the past 1900 years.

(C) 2003 Published by Elsevier Ltd.
\end{abstract}

\section{Introduction}

The largest, $\mathrm{Mw}$ 7.6, earthquake during the last 100 years in Taiwan occurred on September 21, 1999 along the Shihkang, Chelungpu, and Tajienshan Faults (Chen et al., 2000, 2001e). The earthquake rupture is situated at the boundary between the Western Foothills and the Taichung piggyback basin. Based on the historical earthquake record during the past 400 years, the westernmost Foothills have been the most seismically active area (Hsieh and Tsai, 1985). Particularly, several larger and disastrous earthquakes of moment magnitude $M>6.5$, that caused ground ruptures, occurred in this region during the past hundred years, such as the 1906 Meishan, 1935 Taichung-Hsinchu, and 1946 Hsinhua earthquakes (Fig. 1; Omori, 1907; Chang et al., 1947; Bonilla, 1975). The 1792 and 1848 earthquakes also severely damaged this region and caused thousand people killed, producing high-intensity shaking in a $300-\mathrm{km}$-long radius even including parts of Mainland

\footnotetext{
*Corresponding author. Tel.: + 886-2-2369-6594; fax: + 886-2-23636095 .

E-mail address: wenshan@ccms.ntu.edu.tw (W.-S. Chen).
}

China. Seismic modeling of the above two historical earthquakes estimated their magnitude to be about 7.1 (Tsai, 1986). However, it is not known which fault was responsible for which of the two earthquakes. Our paleoseismic study (Chen et al., 2001a,b) however suggested that the penultimate earthquake event of the Chelungpu Fault occurred 300 years or less before present, and that one of the two historical earthquakes must be responsible for the ground rupture along the Chelungpu Fault. Unfortunately, basic information on the paleoseismicity of active faults in western Taiwan are virtually lacking, and therefore, we need urgently to collect data about the recurrence, slip rate, and amount of displacement per event that characterize the Holocene behavior of the Chelungpu Fault in the Western Foothills.

The 1999 surface ruptures in the middle segment of the Chelungpu Fault cut through the Holocene fluvial plain. Two trenches have been made in this study across the fault trace, displaying complicated structural features within unconsolidated sediments which include a triangular ductile shear zone at the fault front. Since offset measurements within the ductile shear zone are too variable to estimate the net slip, this study tried 


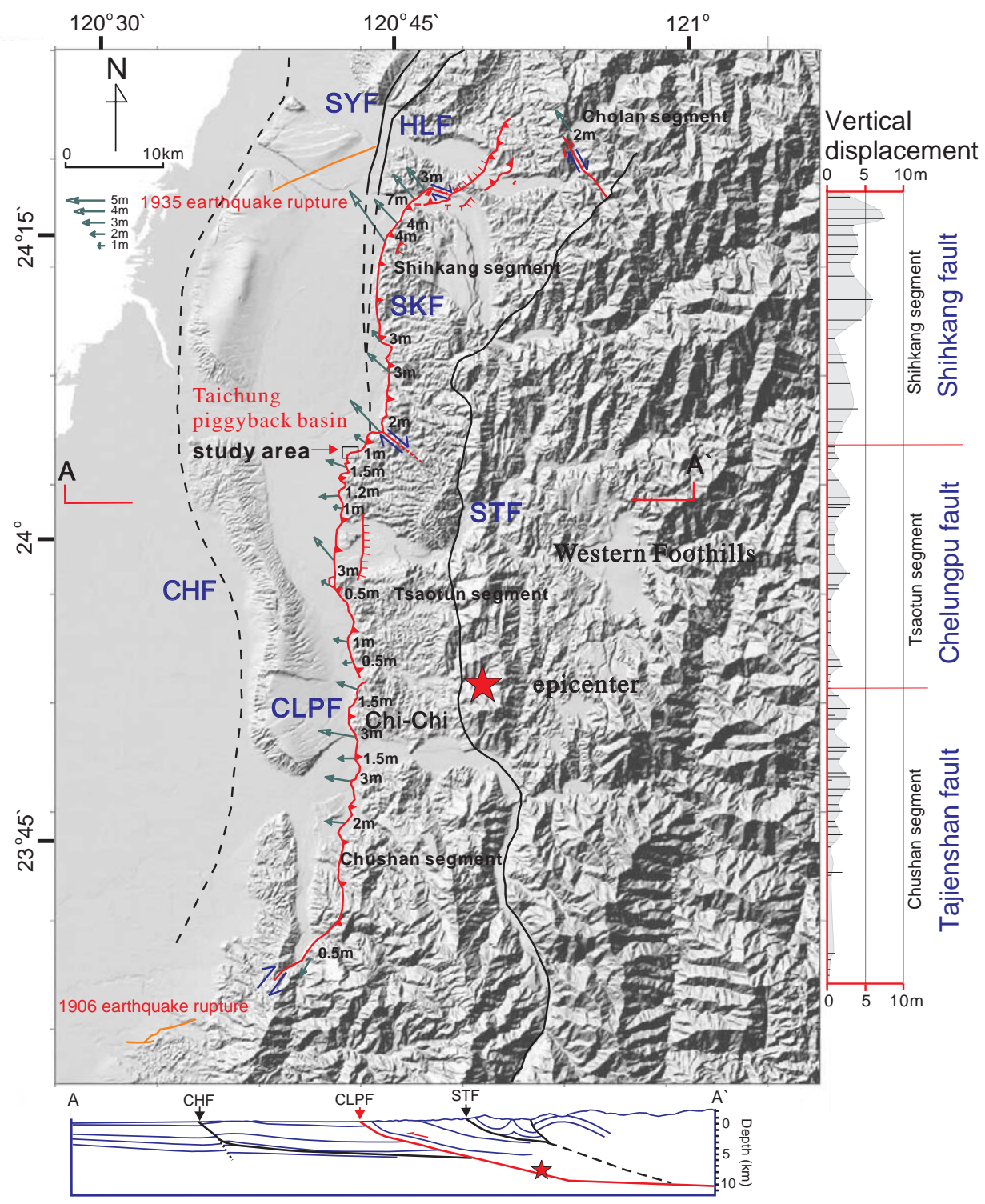

Fig. 1. The Chi-Chi earthquake causes a surface rupture in front of the Western Foothills, which is subdivided into the Chushan, Tsaotun, Shihkang, and Cholan segments along the Shihkang-Chelungpu-Tajienshan Fault (Chen et al., 2001e). The seismic reflection profile is re-projected onto the cross section $\mathrm{A}-\mathrm{A}^{\prime}$.

other methods to estimate a relatively complete slip rate for the thrusting through much more detailed observation and discussion of the characteristics of the surface ruptures.

\section{Tectonic setting}

The fold-and-thrust belts related to the ongoing arc-continent collision are one of the principal tectonic features in western Taiwan. The orogenic belts can be interpreted as the tectonic setting of an accretionary prism on an inferred gently east-dipping detachment fault (Carena et al., 2001a,b;Chen et al., 2001e). The western part of the prism is overthrust on the Holocene deposits along the Changhua Fault. Most of the deformations in the Western Foothills have been formed as hanging wall folds associated with displacement over ramp structures at the beginning of late Pliocene (Chen et al., 2001e). In compressional tectonic environments, active thrust faults commonly occur along frontal fold-and-thrust belt. The Chelungpu Fault, sharply defining the western margin of the foothills, is a main thrust bounded between the PlioPleistocene fold-and-thrust belt to the east and late Quaternary piggyback basin to the west (Fig. 1). Based on the geologic map and seismic reflection profile, the Chelungpu Fault is a thrust dipping about $30^{\circ}$ east with at least $5000 \mathrm{~m}$ stratigraphic separation (Fig. 1; Chiu, 1971). The fault is inferred to have formed at the beginning of the Middle Pleistocene, about $0.7-0.5 \mathrm{Ma}$ (Chen et al., 2001f). 


\section{The Chi-Chi earthquake rupture}

Before the 1999 earthquake, the exact location of outcrop of the Chelungpu Fault was identified at only one site, because huge Holocene alluvial and colluvial deposits buried most of its fault traces. Therefore, it was not until the earthquake that the fault traces were clearly mapped (Fig. 1; CGS, 1999; Ota, 1999; Chen et al., 2000, 2001e; Chen et al., 2002). The 1999 earthquake reactivated the thrust fault, producing a clear surface rupture for about $80 \mathrm{~km}$ along the boundary between the Western Foothills and the Taichung piggyback basin. Based on the geologic characters, the earthquake rupture was segmented into three faults, named from the north, Shihkang, Chelungpu, and Tajienshan Faults (Fig. 1; Chen et al., 2001e). The reactivated Chelungpu Fault shows vertical offset of $0.2-4 \mathrm{~m}$ on the upthrown block of the old Chelungpu Fault (Chen et al., 2001e, g). The surface ruptures trend from $\mathrm{N} 30^{\circ} \mathrm{W}$ to $\mathrm{N} 20^{\circ} \mathrm{E}$ and dip about $20-30^{\circ} \mathrm{E}$. We infer furthermore that the principal compressive stress direction was $\mathrm{N} 70^{\circ}-90^{\circ} \mathrm{E}$ toward the west. The ruptures approximately coincide with the toes of the Foothills along the preexisting Holocene terrace scarps (Chen et al., 2001c; Chen et al., 2002).

Repeated coseismic displacements commonly display clear morphological expressions on both sides of the fault zone. In the vicinity of the present excavation, the 1999 fault runs along the western slope of the foothills with hanging wall uplift of about $0.2-4.0 \mathrm{~m}$ compared to the footwall (Chen et al., 2001e). Tectonic loading and coseismic subsidence occur as an elongate subsidence zone near the front on the footwall forming several sag ponds and lakes evident also from the historical records

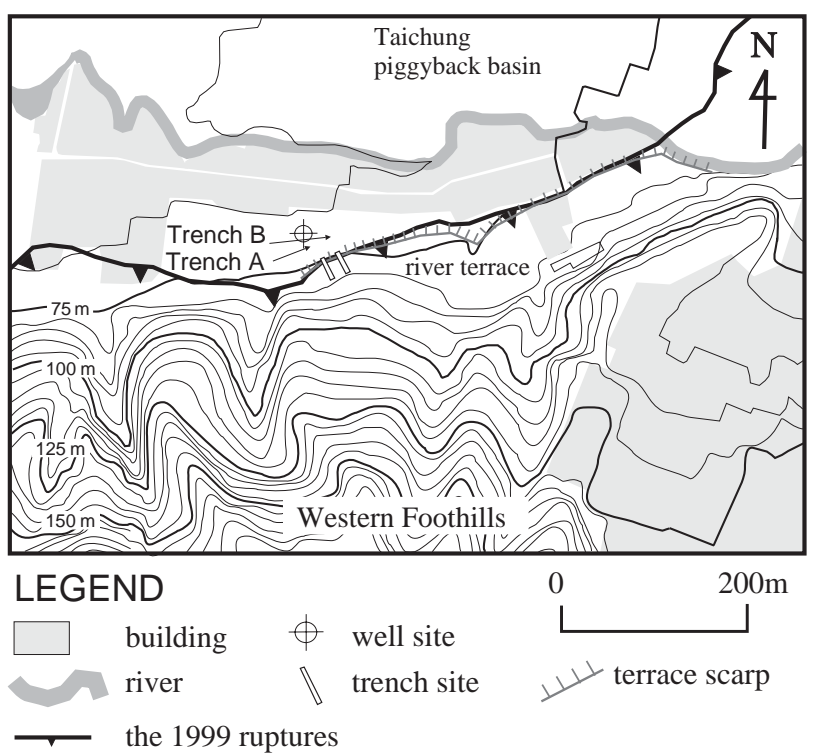

Fig. 2. Location map of the trenches excavated across a terrace scarp along the Chelungpu Fault. and well logs. In addition, streams flowing across the thrust fault from the hanging wall used to make abrupt bends parallel with the active fault at the mountain front (Fig. 2). The geomorphic expression reveals that the Chelungpu Fault has often been active during the Holocene. Repeated activity caused the fault traces to migrate westward and resulted in raised terraces on the hanging wall (Chen et al., 2001a). Topographic mapping of the terraces shows clear multi-stepped scarps. The 1999 rupture also follows the scarps that represent the result of rapidly accumulated effect of repeated earthquakes (Chen et al., 2001c).

\section{Depositional sequence and radiocarbon 14 dates at the pineapple field site}

We excavated two trenches (trenches A and B) across the 1999 rupture and a preexisted terrace scarp (Figs. 2 and 3). The 1999 rupture obviously uplifted the hanging wall by about 1.6-2.1 m (Figs. 3 and 4). Both trenches offered an opportunity to discover paleoseismic faults, and hopefully enable us to estimate slip rate, and recurrence time interval. We opened an approximately southeast-trending, 25-m-long, 8-m-deep trench which gave clear exposures of the Pliocene basement rock, late Pleistocene fluvial deposits and Holocene colluvium (Figs. 3a and b). The fluvial deposits, unconformably overlying the Pliocene basement, contain thick-bedded gravel and massive sandy sediments with some silty sand layers interbedded with gravel beds at the top (Fig. 5). Detrital charcoal samples collected from the fluvial deposits yield four radiocarbon ages (Beta Analytic Inc.,

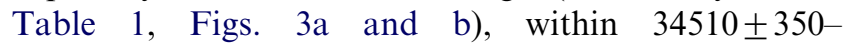
$38880 \pm 570 \mathrm{yr}$ BP (trench A: sample 20010218-1: $38880 \pm 570 \mathrm{yr} \quad$ BP; $20010219-5: \quad 37880 \pm 520 \mathrm{yr} \quad$ BP; 20010226-4: $37330 \pm 470 \mathrm{yr} \mathrm{BP}$; trench B: sample 20010315-1: $34510 \pm 350 \mathrm{yr}$ BP). The fluvial deposits are covered with two distinctly dark brown organic paleosols (s1 and s2) containing a lot of detrital charcoals which give seven radiocarbon dates within an range of 2235-1795 Cal BP for s1 and s2 units (trench A: sample 20010226-1: $1795 \mathrm{Cal}$ BP; 20010220-2: 2010 Cal BP; 20010220-5: 2010 Cal BP; 20010220-1: $1800 \mathrm{Cal} \mathrm{BP}$; trench B: sample 20010319-4: $1795 \mathrm{Cal}$ BP; 20010318-1: 1885 Cal BP; 20010318-4: 2235 Cal BP; Table 1, Figs. 3a and b). The radiocarbon dates obviously indicate that the paleosols disconformably overlay the fluvial deposits. This disconformity is indicative of terrestrial erosion and weathering, probably developed since the last glacial stage.

The ground surface is covered with a layer of recent organic soil overlying a series of interbedded silty sand and gravel deposits that we interpret as colluvial deposits of about $3.5 \mathrm{~m}$ in thickness. Based on the gravel composition, the colluvium is evidently derived 


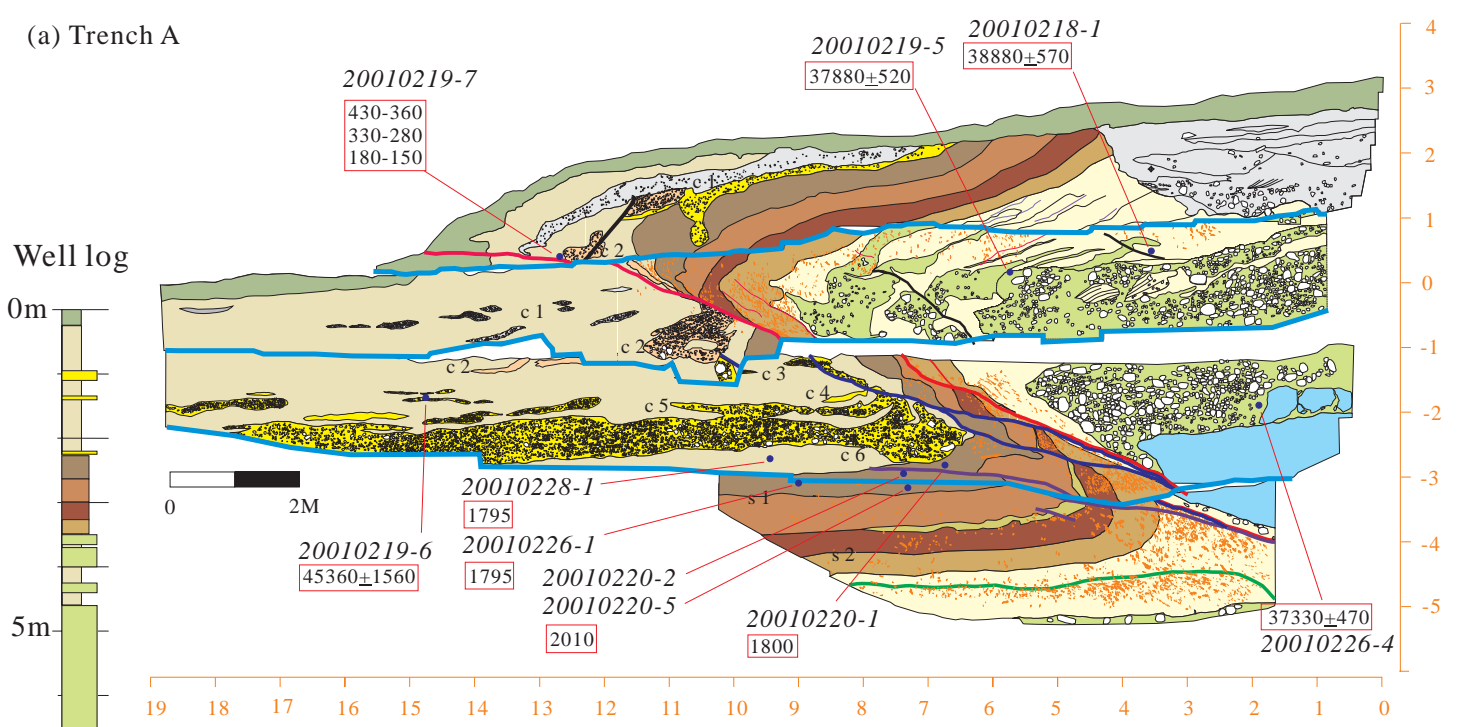

(b) Trench B
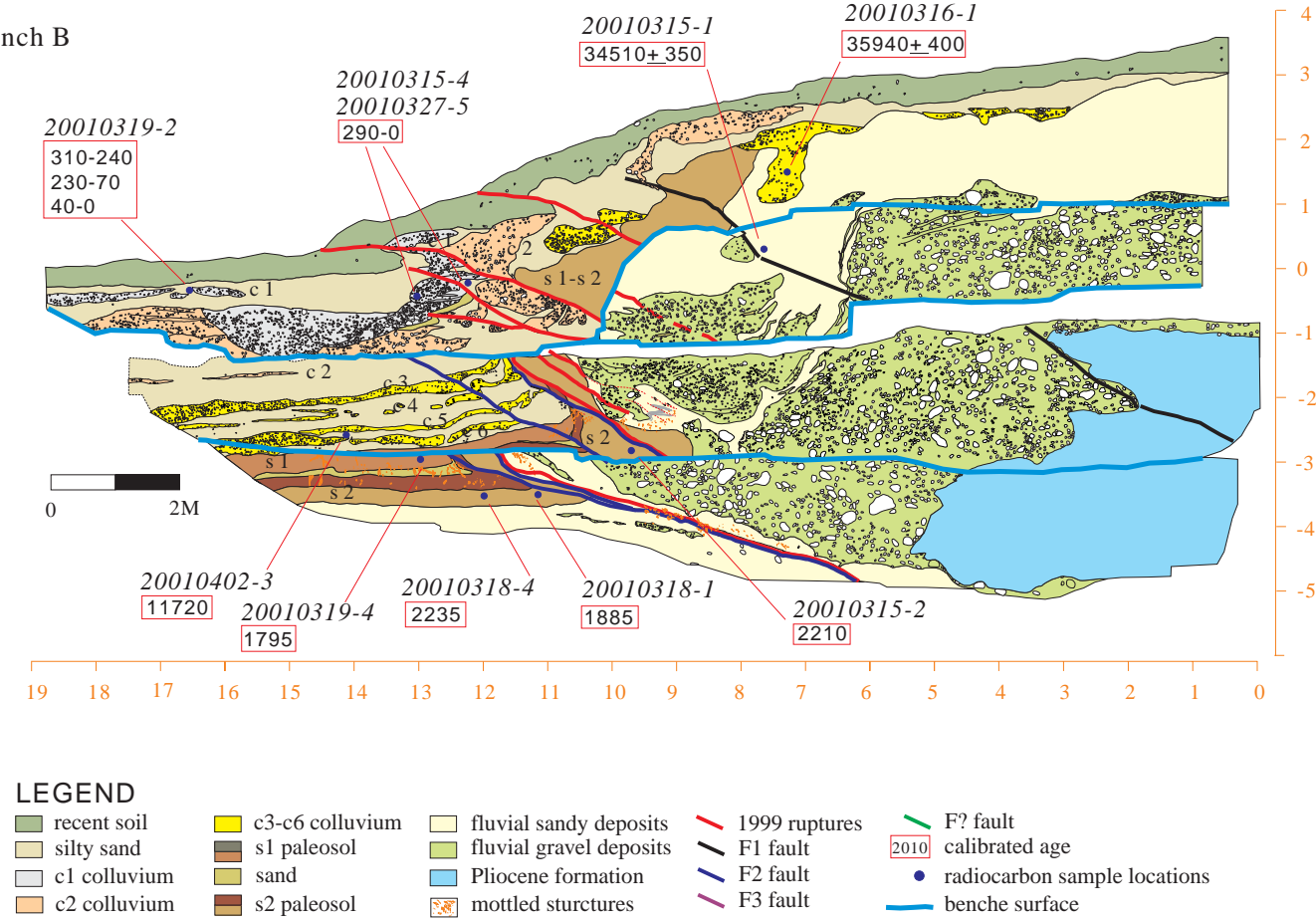

Fig. 3. (a, b) Five types of deposits, the 1999 ruptures, and three paleo-coseismic thrusts of F1, F2, and F3 are observed in the trench. The Pliocene basement is overthrust on the hanging wall. The older sediments of the fluvial gravel deposits reached at $2 \mathrm{~m}$ depth on the hanging wall and $5 \mathrm{~m}$ depth on the footwall. The fluvial gravel deposits have $6 \mathrm{~m}$ vertical offset across the main fault. The top soil is offset $1.6 \mathrm{~m}$ at trench A and $2.1 \mathrm{~m}$ at trench B in both sides of the 1999 ruptures.

from the surrounding foothills of late Pliocene rocks. It is essentially composed of alternating wedge- and layershape gravel beds consisting of subangular sandstone gravels (c1-c6). Sedimentation of coarse-grained colluvium is commonly generated with storm- or earthquakeinduced deposits. Particularly, in the subtropical region, such deposition prevails during a storm season when huge sediments are deposited on the foothill front. Thinbedded gravel beds of $\mathrm{c} 3$ and $\mathrm{c} 4$ colluvial deposits display the matrix-supported structure revealing a storm-induced deposition by debris flows. Wedgeshaped deposits of $\mathrm{c} 1, \mathrm{c} 2$, and $\mathrm{c} 5-\mathrm{c} 6$ displaying the 


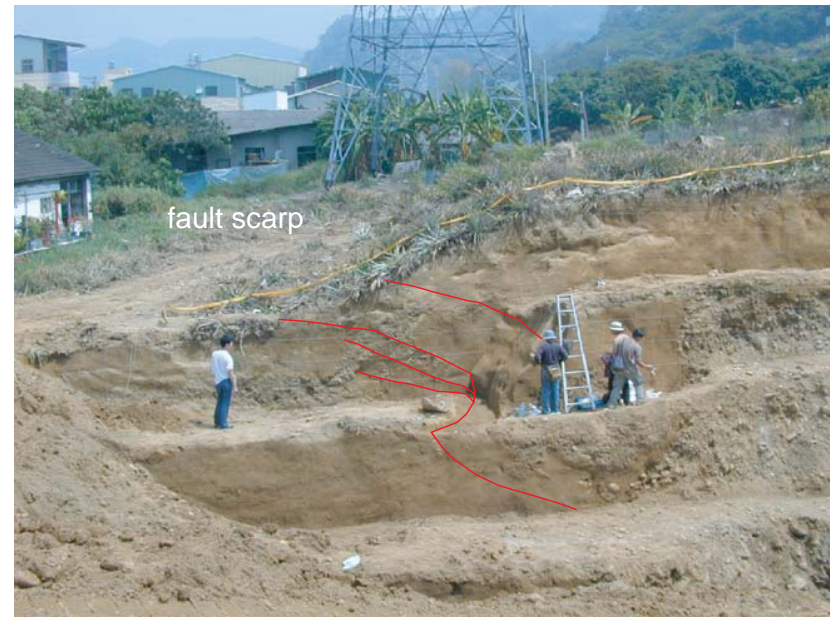

Fig. 4. The fault scarp offsets the river terrace. The height of the fault scarp is $2.1 \mathrm{~m}$ in trench B. The 1999 rupture near the ground surface is bifurcated to four reverse faults.

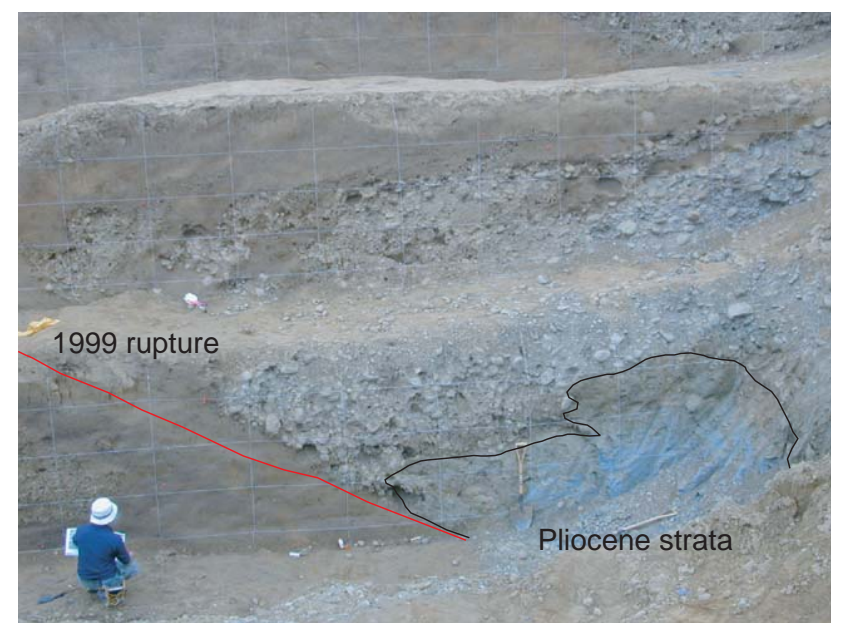

Fig. 5. In trench A, the Pliocene basement is overthrust on the Holocene colluvial deposits along the 1999 rupture. The late Pleistocene fluvial deposits unconformably overlying the Pliocene strata are dragged to form an anticline on the hanging wall.

clast-supported structure overlay the paleoearthquake ruptures, indicating that the colluvium evidently represents the earthquake-induced deposits (Schwartz and Coppersmith, 1984). Radiocarbon analysis of charcoals constrains the age of the oldest colluvial layer (c6) to be about 1795 Cal BP (trench A: sample 20010228-1; Table 1, Fig. 3a). The sequence of the colluvium overlying the fluvial deposits indicates that the foothills progressively approached an older stream, which was covered by deposition of the younger colluvium (c6) about 1900 years ago if we take the older limit of the above age into calculation. At this time, the stream probably diverted its course and migrated away from the foothills toward the Taichung basin. We interpret that the change of the depositional environment reflects westward foothill propagation because of earthquake events.
The uppermost colluvial layer (c1) yields four calibrated ages (trench A: sample 20010219-7: 430360 Cal BP, 330-280 Cal BP, 180-150 Cal BP, 10-0 Cal BP; trench B: sample 20010319-2: 310-240 Cal BP, 23070 Cal BP, 40-0 Cal BP; 20010315-4 and 20010327-5: 290-0 Cal BP; Table 1, Figs. 3a and b). The last two charcoal samples were collected within the c1 colluvium, sample 20010319-2 between the top soil and $\mathrm{cl}$ colluvium, and sample 20010219-7 between c1 and c2 colluvium. These radiocarbon dates may be interpreted to constrain the depositional age of $\mathrm{cl}$ colluvium to be younger than 430 years ago. The $\mathrm{c} 1$ colluvium may be deposited in response to the penultimate earthquake event, suggesting that the age of the event is younger than 430 years. On the other hand, the historical earthquake documents for the past four centuries provide evidence that the largest earthquake occurred more than 150 years ago in this area. We suggest therefore that the penultimate event occurred within the range of 430-150 years. This result is compatible with our previous observation of two excavations at Wanfung and Mingjian (Chen et al., 2001a,b). The ground rupture of fault $F 1$, with about $1 \mathrm{~m}$ vertical offset, is close to the observation at Wanfung and Mingjian of 0.4 and $1 \mathrm{~m}$ vertical offset, respectively. Incidentally, radiocarbon ages of charcoal samples 2010219-6 $(45360 \pm 1560 \mathrm{yr}$ BP $), 20010402-3$ (11720 Cal BP) and 20010316-1 (35940 \pm 400 yr BP; Table 1, Figs. 3a and b), which are all collected from the colluvial deposits, are considerably older than the ages of the host paleosol and colluvial deposits. We interpret that these older charcoals may have been mixed into the colluvial deposits through erosion from former ground surfaces.

\section{Structural features of the earthquake fault}

The 1999 rupture at the trenching sites forms a $\mathrm{N} 42^{\circ} \mathrm{E}$ trending, and $26^{\circ}$ southeast-dipping fault plane. Determination of faulting succession using structural features is commonly not easy, but the excavation, fortunately, revealed an interesting feature of the deformed weathered mottle structure which serves as a key horizon (Fig. 6). Intersection relationships show that the shear zone produced by the 1999 earthquake cuts through and deforms the mottled structure, and the latter is seen to truncate and disturb a preexisting fault zone that represents another paleoearthquake event.

The 1999 fault here displays a fault-bend fold geometry forming a flat-and-ramp structure on the frontal upthrown block (Figs. 3a and b). The wedgeshaped deformation zone shows inhomogeneous ductile deformation comprising a hanging wall anticline and a footwall syncline with an overturned limb and increasing thickness in the axial part. The top soil layer obviously rolls over to form a part of the recumbent 
Table 1

Calculated dates from C14 analysis of charcoals collected at trenches A and B (Figs. 2a and b)

\begin{tabular}{|c|c|c|c|c|c|}
\hline Sample no. & Location & Lab. number & $\begin{array}{l}\text { Conventional } \\
\text { radiocarbon age }\end{array}$ & Calibrated years BP & Sample horizon \\
\hline 20010218-1 & Trench A & Beta-159306 & $38,880 \pm 570$ & & Fluvial sandy deposits \\
\hline $20010219-5$ & Trench A & Beta-159301 & $37,880 \pm 520$ & & Fluvial gravel deposits \\
\hline $20010219-6$ & Trench A & Beta-159302 & $45,360 \pm 1560$ & & $\mathrm{c} 3$ \\
\hline $20010219-7$ & Trench A & Beta-159305 & $260 \pm 40$ & $\begin{array}{l}430-360 \\
330-280 \\
180-150 \\
10-0\end{array}$ & $\mathrm{cl} / \mathrm{c} 2$ \\
\hline 20010220-1 & Trench A & Beta-159296 & $1870 \pm 50$ & $1900-1700$ & s1 paleosol \\
\hline 20010220-2 & Trench A & Beta-159297 & $2050 \pm 40$ & $2120-1900$ & s1 paleosol \\
\hline $20010220-5$ & Trench A & Beta-159298 & $2050 \pm 40$ & $2120-1900$ & s1 paleosol \\
\hline 20010226-1 & Trench A & Beta-159309 & $1860 \pm 40$ & $1880-1710$ & s1 paleosol \\
\hline $20010228-1$ & Trench A & Beta-159299 & $1860 \pm 40$ & $1880-1710$ & c6/s1 paleosol \\
\hline 20010315-1 & Trench B & Beta-159314 & $34,510 \pm 350$ & & Fluvial sandy deposits \\
\hline 20010315-2 & Trench B & Beta-159310 & $2200 \pm 40$ & $2330-2120$ & s2 \\
\hline 20010315-4 & Trench B & Beta-159319 & $150 \pm 40$ & $290-0$ & $\mathrm{cl}$ \\
\hline 20010316-1 & Trench B & Beta-159321 & $35940 \pm 400$ & & c3-c6 \\
\hline 20010318-1 & Trench B & Beta-159317 & $1930 \pm 40$ & $1960-1810$ & s2 \\
\hline 20010318-4 & Trench B & Beta-159315 & $2200 \pm 40$ & $2340-2130$ & s2 \\
\hline 20010319-2 & Trench B & Beta-159311 & $200 \pm 5$ & $\begin{array}{l}310-240 \\
230-70 \\
40-0\end{array}$ & $\mathrm{cl}$ \\
\hline $20010319-4$ & Trench B & Beta-159322 & $1860 \pm 40$ & $1880-1710$ & s1 \\
\hline $20010327-5$ & Trench B & Beta-159313 & $160 \pm 40$ & $290-0$ & $\mathrm{cl}$ \\
\hline $20010402-3$ & Trench B & Beta-159318 & $10760 \pm 60$ & $\begin{array}{l}12,990-12,780 \\
12,760-12,630\end{array}$ & c3-c6 \\
\hline
\end{tabular}

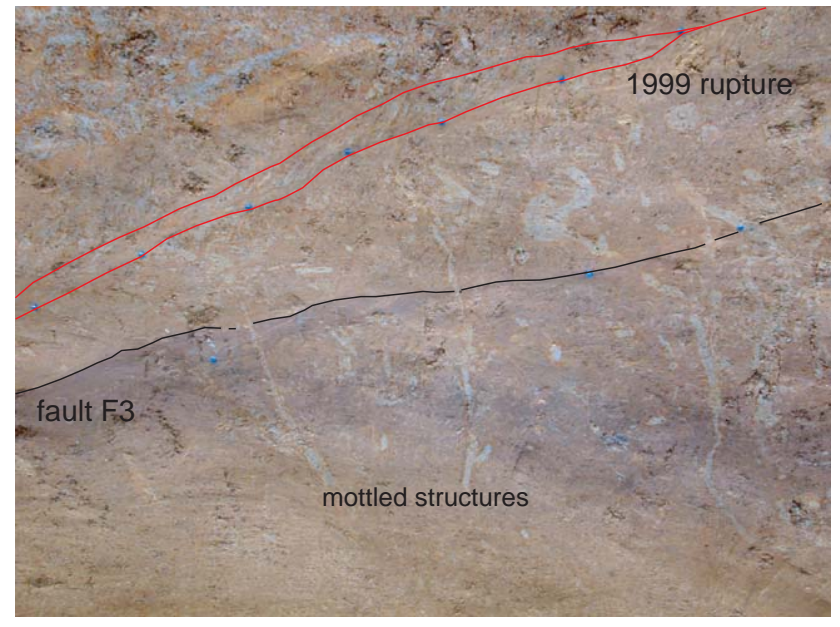

Fig. 6. The 1999 rupture formed a shear zone within the paleosol layer. The shear plane cuts through the mottled tubular structures that truncate the preexisting $\mathrm{F} 3$ in trench $\mathrm{B}$.

anticline at the fault front. In trench $\mathrm{B}$, the rupture within the ductile deformation zone is bifurcated into four reverse faults (Fig. 3b), while at trench A it just developed into one main thrust (Fig. 3a), which dips $26^{\circ}$ towards the east and is defined by $0.5-1 \mathrm{~m}$ wide zone of massive sandy layer with locally developed several thin shear zones and pebbles aligned parallel to the fault plane. Based on the stratigraphic dislocation in both sides of the 1999 fault zone, the vertical offset along the ramp is 1.6 and $2.1 \mathrm{~m}$ in trenches $\mathrm{A}$ and $\mathrm{B}$, respectively.

The trench exposes three paleoearthquake thrust faults of F1, F2, and F3 (Fig. 3b). F1 exposed at trench $\mathrm{B}$ cuts through the Pliocene basement, fluvial, and colluvial deposits in the hanging wall of the main fault. At trench A, we found a minor fault which cut through c2 bed and overlaid by $\mathrm{c} 1$ at the fault tip, but flexed bedding (s1-s2) and several minor reverse faults suggest its presence on the hanging wall (Fig. 3a). At trench B, the deformation within the fluvial deposits, c2, and c3c6 colluvial deposits displays a fault-bend fold along F1. At the third bench in trench $\mathrm{B}$, the Pliocene basement has $1.0 \mathrm{~m}$ vertical and $1.45 \mathrm{~m}$ horizontal offsets displaying a $32^{\circ}$ dipping fault plane (Figs. $3 \mathrm{~b}$ and 5). However, the unconsolidated sediments at the fault front exhibits $0.1 \mathrm{~m}$ vertical offset and $0.2 \mathrm{~m}$ horizontal offset which is less than that of the basement on the lower reaches of the fault (Fig. 3b). Through the stratigraphic correlation, F1 cuts through the lower colluvium (c2-c6) and does not break the surface soil in trench $\mathrm{B}$, which is the evidence for the penultimate event ( $\mathrm{N}-1$ event). We interpret that the $\mathrm{c} 1$ colluvium was deposited in response to the penultimate earthquake.

F2, exposed underneath the main fault, evidently cuts through colluviums c3-c6 and is overlain by c2 wedgeshaped colluvium, providing evidence for faulting prior to deposition of $\mathrm{c} 2$ colluvium (Figs. $3 \mathrm{a}$ and $\mathrm{b}$ ). At trench 
A, the base of $\mathrm{c} 2$ has a west-dipping slope, suggesting that it was deposited on a pre-existing west-facing scarp. F2 at trench A branches into several reverse faults, which are truncated at an overturned synclinal limb and merge with the main thrust downward. In addition, trench $\mathrm{B}$ in the third bench reveals that $\mathrm{c} 4, \mathrm{c} 5$, and $\mathrm{c} 6$ colluvial beds form a dragged synclinal structure on the footwall. The vertical offset by these faults amounts to up to about $1 \mathrm{~m}$. The fault zone has dip angle of $25^{\circ}$ eastward in the third bench, reducing downward to $16^{\circ}$ where it merges with the main fault in the fourth bench.

Satisfactory excavation can identify the record of the 1999 earthquake and three paleoseismic events. Trench B clearly exposes F3, which is approximately parallel with F2 and the 1999 rupture and merges with the two faults in the fourth bench (Fig. 3b). That we were not able to find the fault trace of F3 in trench A suggests that F2 and 1999 rupture took place probably along the pre-existing F3. Based on the well log, a fluvial gravel bed exists at the depth of $5 \mathrm{~m}$ on the footwall, and a corresponding fluvial gravel bed on the excavation has $6 \mathrm{~m}$ vertical offset across the main fault. Between the amount of vertical offsets produced by the 1999 and last two events $(\mathrm{N}-1$ and $\mathrm{N}-2)$ and the above accumulated amount, there exists $2.2 \mathrm{~m}$ difference, which can be interpreted as strong evidence for the probable occurrence of at least another paleoseismic event $(\mathrm{N}-3 / \mathrm{N}-4)$. In addition, evidence of the structural features of F2 also suggests at least another event. Close observation on the relationship of the complicated structure indicates that the overturned synclinal limb is truncated by F2 in trench A (Fig. 3a). It reveals that a synclineforming process had been developed prior to F2, and then F2 cut through the synclinal forelimb. The c6 colluvial deposit is overlaid on F3 in the third bench of trench A. We interpret here that the N-3 earthquake event occurred along with F3 of the main fault and also produced that syncline on the footwall, between the time interval of formation of the dark brown paleosol and deposition of the c6 colluvium. The c6 colluvium was probably deposited in response to the $\mathrm{N}-3$ earthquake event.

\section{Estimation of the slip rate}

The weathered mottled structures in a tubular form occur within paleosols and sandy fluvial deposits, which are approximately perpendicular to the bedding plane within undisturbed deposits. The vertical tubular structures have approximately circular horizontal cross sections and are reddish to whitish gray in color in contrast to yellowish ocher of the paleosol, probably acting as leaching pipes for percolating water from old surfaces. The mottled structures near a fault zone are dragged to display a wicker-form by shearing. It is easy to measure these structures in oriented cube blocks of soil cut from the disturbed deposits. By careful peeling off of the soil cakes, the long axes of the tubes are seen to commonly represent the maximum extended orientation and provide a good constraint on the slip direction. Measurements of several tens of such orientations enable us to obtain the average slip directions of $\mathrm{N} 40^{\circ} \mathrm{W}, \mathrm{N} 22^{\circ} \mathrm{W}$ and $\mathrm{N} 20^{\circ} \mathrm{W}$ in the shearing plane of the 1999 rupture (fault plane orientation: $\mathrm{N} 42^{\circ} \mathrm{E}$, $\left.\mathrm{SE} 26^{\circ}\right)$, for fault $\mathrm{F} 1\left(\mathrm{~N} 68^{\circ} \mathrm{E}, \mathrm{S} 32^{\circ}\right), \mathrm{F} 2\left(\mathrm{~N} 68^{\circ} \mathrm{E}, \mathrm{S} 25^{\circ}\right)$, and $\mathrm{F} 3$ (about $\mathrm{N} 40^{\circ} \mathrm{E}, \mathrm{SE} 18^{\circ}$ ), respectively. The slip direction measured with the above method along the 1999 rupture of the main fault generally agrees with that of the present surface rupture in this region. Because the trend of the excavated section, about $\mathrm{N} 40^{\circ} \mathrm{W}$, is parallel with the slip direction of the 1999 rupture, we can obtain its net slip directly from the measured offset of the 1999 rupture on the excavated section. However, the measured slips for F1 and F2 represent an apparent displacement, because the trend difference between the slip and excavation amounts to about $20^{\circ}$. Hence we should project the measured displacement on the excavation plane to a reference vertical plane along the slip direction to estimate the true amount of slip. On the other hand, the vertical offsets from the both trenches are $1.6-2.1 \mathrm{~m}$ for the 1999 rupture, $1.0-0.75 \mathrm{~m}$ for $\mathrm{F} 1,1.1-1.0 \mathrm{~m}$ for $\mathrm{F} 2$, and $2.3-2.15 \mathrm{~m}$ for the $\mathrm{N}-3 / \mathrm{N}-$ 4 ? events, respectively. Each value from one trench is different from that from the other trench by several decimeters. Such differences are consistent with the result from the measured vertical offsets of the 1999 surface rupture where the common difference range is from several decimeters to one meter, even within a small segment. The average amounts of net slip along the individual fault planes is $4.2 \mathrm{~m}$ for the 1999 earthquake, $2.0 \mathrm{~m}$ for $\mathrm{N}-1,2.9 \mathrm{~m}$ for $\mathrm{N}-2$, and $7 \mathrm{~m}$ for $\mathrm{N}-3 / \mathrm{N}-4$ ? events. To determine the slip rate per event, it is necessary to estimate the timing of surface-faulting events and displacement. Since the radiocarbon analysis determines that the penultimate event occurred less than 430 years ago, the minimum slip rate is calculated to be about $8.6 \mathrm{~mm} / \mathrm{yr}$. Although the depositional age of the c2 wedge-shaped colluvium seems to closely represent the $\mathrm{N}-2$ event, we have not yet obtained any better constraints on the date of this event. Therefore we are only able to estimate roughly that the average slip rate is about $8.5 \mathrm{~mm} / \mathrm{yr}$ for the past 1900 years.

\section{Discussion}

For the estimation of the slip rate, we need to describe the deformation features in more detail, so that we may be able to provide a useful analytical tool for the prediction and calculation of the amount of displacement per event. In both excavations, we find a triangular ductile shear zone at the fault front forming a recumbent 
anticline on the hanging wall and syncline on the footwall (Figs. 7a and b). The triangular geometry of disturbed zone displays several heterogeneous deformation features such as curved fold hinges, bedding thickening in fold hinges and bedding dip changes along the 1999 rupture and F1. These features found here seem to be consistent with the trishear model of a heterogeneous hanging-wall-fixed trishear of fault propagation folding (Erslev, 1991). Based on this model, faulting used to bring about inconsistency in displacement caused by the ductile deformation (Dahlstrom, 1969); the amount of slip along the fault near the surface within the trishear zone is much less than that toward the lower reaches because part of the shortening is absorbed in bedding thickening (Erslev, 1991; Hardy and Ford, 1997). For example, F1 in trench B shows that the slip on the lower reaches (the third bench) of the fault is $1.8 \mathrm{~m}$, which is much greater than that toward the surface (the first bench) of $0.2 \mathrm{~m}$ within the wedgeshaped ductile shear zone (Fig. 3b). As the trishear model (Hardy and Ford, 1997) predicts, the 1999 rupture in trench B further shows several minor faults at the front. On the contrary, the hanging wall strata away from the trishear zone are free from deformation (Erslev, 1991), and here the slip on the hanging wall represents the actual displacement of the upthrown block. Both excavations expose resistant Pliocene rocks as actual hanging wall basements (Figs. 7a and b). Here the basement tip can be regarded as the initial fault tip of the 1999 rupturing, and the end of fault tip already cut through the ground surface. The apical angle of the trishear deformation zone for the 1999 rupture is measured to be about $45-55^{\circ}$ to upturn (Figs. $7 \mathrm{a}$ and b). In a hanging-wall-fixed trishear of fault propagation folding, the structural relief on the hanging wall is equal to the vertical separation of basement along the lower reaches of the fault beyond the trishear zone. Actually, the slip rate is dependent on the dip of the thrust (Champion et al., 2001). Outside of the trishear zone, then, the actual slip on the upthrown block can be determined from the structural relief and dip of the fault along the slip direction.
Based on the measured structural relief on the hanging wall, we can obtain the average slip rate of $8.5 \mathrm{~mm} / \mathrm{yr}$ for the past 1900 years and the minimum slip rate of $8.6 \mathrm{~mm} / \mathrm{yr}$ since the penultimate event. The vertical component of the above figures may be used for comparison with the long-term uplifting rate across the fault. Judging from the stratigraphic elevation difference of the Pliocene formation, the stratigraphic separation across the fault is about $5000 \mathrm{~m}$ since 0.7-0.5 Ma (Chang, 1971; Chiu, 1971; Suppe, 1981; Chen et al., 2000e, 2001f). The longer-term uplifting rate is estimated to be about $7-10 \mathrm{~mm} / \mathrm{yr}$, which is incompatible with the average vertical slip rate or uplifting rate of $3.2 \mathrm{~mm} / \mathrm{yr}$ for the past 1900 years. This discrepancy may be accounted for by several means. First, the slip may have become slower for the past 1900 years, or since the outset of the collision. Secondly, it may be due to a dimension problem. In other wards, we cannot escape from the possibility that the dimension where we made the measurements is actually contained in a larger dimension as a trishear zone. Thirdly, the smaller uplifting rate is simply due to the fact that our excavation area is too small to include all fault slips. Several fault traces actually occurred in a wider area that are several tens to hundred meters far away from the main fault during an individual earthquake, such as we have noticed at the Wanfung and Mingjian sites (Chen et al., 2001a,b). Well logs in the vicinity of the present excavation also show several fault zones separated at intervals of several tens meters depth underneath the surface, displaying the sequence of the Pliocene basement overthrusting on the gravel deposits as imbricate faults. In some places, the 1999 ruptures also have double ground fault traces (CGS, 1999) as a series of imbricate splay faults at the fault front. For this reason, we may consider the possibility that both trenches in this study may be insufficient in width and depth to expose all coseismic faults for the past 1900 years. If it is the case, then the estimated uplifting and slip rate in this paper is too small, and the average recurrence interval time is too long.

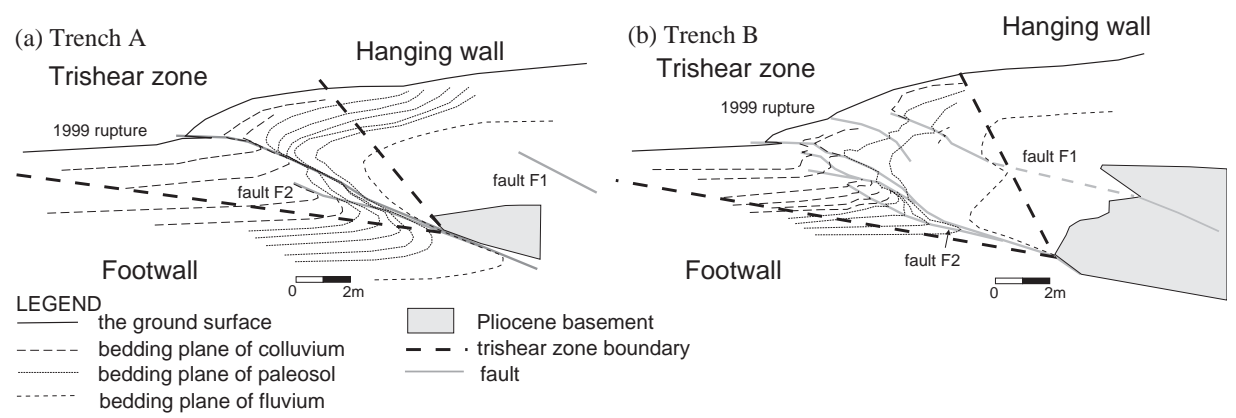

Fig. 7. (a, b) Trishear deformation zone resulted from the 1999 earthquake rupturing. Fault tips cut through the ground surface during the earthquake. 


\section{Conclusions}

Earthquake-related surface faulting and folding usually comprise a trishear ductile deformation zone at the fault front which displays several distinctive structures, such as bedding thickening in the fold axis, recumbent folding in both sides of fault, and increased bedding dip toward the lower reaches of the fault plane. Through our excavated experience for the 1999 ruptures (Chen et al., 2001a, b, d), most excavations show that the surface deformation follows the trishear model of fault propagation folding. The measured displacement within the trishear zone, therefore, is inevitably rather less than the real amount, resulting in a smaller slip rate. We recommend that calculation of the true slip rate for the paleoseismic study, care must be taken in measuring the vertical offset on the undisturbed hanging wall but not within the trishear zone. Furthermore, excavations should be wide and deep enough to cover both undisturbed hanging and foot walls.

The two trenches in this study clearly exposed the 1999 rupture and at least three Holocene paleoearthquake surface faults across the Chelungpu Fault. If we assume that no other significant paleoseismic faults than the above are existent, the following tentative conclusion may be drawn. Above all, based on the radiocarbon dates and historical record, fault F1 (N-1) occurred during $430-150 \mathrm{yr}$ B.P. The penultimate event was also found from the other trenching sites, and it occurred in 300-500 yr BP (Chen et al., 2001a, b; Ota et al., 2001). Fault F2 (N-2) truncated and deformed c3-c6 colluvial deposits and was covered by c2 colluvial wedge deposits. Although the $\mathrm{N}-2$ event is not well constrained by the radiocarbon dating, it is evident that this event occurred after the deposition of $\mathrm{c} 3$ colluvium. Because the colluvial wedge $\mathrm{c} 6$ was produced by the $\mathrm{N}-3$ earthquake, this event probably occurred $1900 \mathrm{yr}$ BP. Therefore, we roughly estimate that the Chelungpu Fault has been active and produced large earthquakes with an average recurrence interval of less than 700 years since 1900 years B.P. Based on the ca. $6 \mathrm{~m}$ vertical offset of paleosol and fluvial deposits, the average slip rate for the past 1900 years is estimated to be about $8.5 \mathrm{~mm} / \mathrm{yr}$. The estimated uplifting rate of about $3.2 \mathrm{~mm} / \mathrm{yr}$, however, has been considered significantly less than the longerterm uplifting rate of $7-10 \mathrm{~mm} / \mathrm{yr}$ since the late Pleistocene. Hopefully, this problem may be resolved by future trenching and study.

\section{Acknowledgements}

The work was supported by National Science Council of Taiwan (NSC91-211P-M-002-022) and by the Central Geological Survey of Taiwan (PIEC2A380104).

\section{References}

Bonilla, M.G., 1975. A review of recently active faults in Taiwan. United States Geological Survey Open-File Report 75-41, Washington, 58pp.

Carena, S., Suppe, J., Kao, H., 2001a. How the 1999 Chi-Chi, Taiwan, Earthquake helped reveal the structure beneath Central Taiwan. American Geophysical Union 2000 Fall Meeting, abstract, F883. American Geophysical Union, Washington.

Carena, S., Kao, H., Suppe, J., 2001b. Imaging the active detachment of the Taiwan Mountain belt. Geological Society of China, 2001 Geology Annual Meeting, Taipei, abstract, p. 19.

CGS, 1999. Report of the geological survey of the 1999 ChiChi earthquake. Central Geological Survey, Taipei, 315pp. (in Chinese).

Champion, J., Muller, K., Tate, A., Guccione, M., 2001. Geometry, numerical models and revised slip rate for the Reelfoot fault and trishear fault-propagation fold, New Madrid seismic zone. Engineering Geology 62, 31-49.

Chang, S.S.L., 1971. Subsurface geologic study of the Taichung basin, Taiwan. Petroleum Geology of Taiwan 8, 21-45.

Chang, S.S.L., Chou, M., Chen, P.Y., 1947. The Tainan Earthquake of December 5, 1946: bulletin. Central Geological Survey of Taiwan $1,11-20$.

Chen, W.S., Chen, Y.G., Liu, T.K., Huang, N.W., Lin, C.C., Sung, S.H., Lee, K.J., 2000. Characteristics of the Chi-Chi earthquake ruptures. Central Geological Survey Special Publication 12, $139-154$.

Chen, W.S., Chen, Y.G., Chang, H.C., 2001a. Paleoseismic study of the Chelungpu fault in the Mingjian area. Western Pacific Earth Sciences 1 (3), 351-358.

Chen, W.S., Chen, Y.G., Chang, H.C., Lee, Y.H., Lee, C.C., 2001 b. Paleoseismic study of the Chelungpu fault in the Wanfung area. Western Pacific Earth Sciences 1 (4), 443-472.

Chen, W.S., Chen, Y.G., Shih, R.C., Liu, T.K., Huang, N.W., Lin, C.C., Sung, S.H., Lee, K.J., 2001c. Thrust-related river terrace development in relation to the 1999 Chi-Chi earthquake rupture, Western Foothills, Central Taiwan. Journal of Asian Earth Sciences 21, 473-480.

Chen, W.S., Chen, Y.G., Lee, C.T., Hsieh, M.L., Chyi, S.J., 2001d. Neotectonic and Paleoseismic studies. Central Geological Survey, 2001 Final Report, Taipei, 107pp. (in Chinese).

Chen, W.S., Huang, B.S., Chen, Y.G., Lee, Y.H., Yang, C.N., Lo, C.H., Chang, H.C., Sung, Q.C., Huang, N.W., Lin, C.C., Sung, S.H., Lee, K.J., 2001e. Chi-Chi earthquake, 1999 September 21: a case study on the role of thrust-ramp structures for generating earthquakes. Bulletin of the Seismological Society of America 91, 986-994.

Chen, W.S., Ridgway, K.D., Horng, C.S., Chen, Y.G., Shea, K.S., Yeh, M.G., 2001f. Stratigraphic architecture, magnetostratigraphy, and incised-valley systems of the Pliocene-Pleistocene collisional marine foreland basin of Taiwan: eustatic and tectonic controls on deposition. Geological Society of America Bulletin 113, 1249-1271.

Chen, Y.G., Chen, W.S., Lee, J.C., Lee, Y.H., Lee, C.T., Chang, H.C., Lo, C.H., 2001g. Surface rupture of 1999 Ch-Chi earthquake yields insights on active tectonics of Central Taiwan. Bulletin of the Seismological Society of America 91, 977-985.

Chen, Y.G., Chen, W.S., Wang, Y., Lo, P.W., Liu, T.K., Lee, J.C., 2002. Geomorphic evidence for prior earthquakes: lessons from the 1999 chichi earthquake in Central Taiwan. Geology 30, 171-174.

Chiu, H.T., 1971. Folds in the northern half of western Taiwan. Petroleum Geology of Taiwan 8, 7-19.

Dahlstrom, D.C.A., 1969. Balanced cross sections. Canadian Journal of Earth Sciences 6, 743-757. 
Erslev, E.A., 1991. Trishear fault-propagation folding. Geology 19, 617-620.

Hardy, S., Ford, M., 1997. Numerical molding of trishear fault propagation folding. Tectonics 16, 841-854.

Hsieh, U.S., Tsai, M.B., 1985. Historical Earthquakes Catalogue in China. Beijing press, Beijing, pp. 1-4.

Omori, F., 1907. Earthquake of the Chiayi area, Taiwan, 1906. Introduction to earthquakes. Seisimological Institute, Imperial University of Japan, pp. 103-147 (In Japanese).

Ota, Y., 1999. Characteristics of earthquake fault by the 921 Chichi earthquake, Central Taiwan, especially on the relationship between earthquake fault and pre-existing quaternary active fault. Proceedings of the International workshop on Chi-Chi Taiwan earthquake of September 21, 1999. Vol. 4, pp. 1-4, 12.
Ota, Y., Huang, C.Y., Yuan, P.B., Sugiyama, Y., Lee, Y., Watanabe, M., Sawa, H., Yanagida, M., Sasaki, S., Suzuki, Y., Hirouchi, D., Tangiguchi, K., 2001. Trenching study at the Tsaotun site in the central part of the Chelungpu fault, Taiwan. Western Pacific Earth Sciences 1 (4), 487-498.

Schwartz, D.P., Coppersmith, K.J., 1984. Fault behavior and characteristic earthquakes: examples from the Wasatch and San Andreas fault zones. Journal of Geophysics Research 89 (B7), 5681-5698.

Suppe, J., 1981. Mechanics of mountain building and metamorphism in Taiwan. Memoir Geological Society of China 4, 67-89.

Tsai, Y.B., 1986. A study of disasterous earthquakes in Taiwan, 16831895. Bulletin of the Institute of Earth Sciences, Academia Sinica 5, $1-44$. 